\title{
Structural Analysis and Distribution Patterns in Lowland Tropical Forest, Eastern Amazon
}

\author{
João da Luz Freitas \\ Dept. of Botany, Institute of Scientific and Technological Research of the State of \\ Amapá, Macapá, Brazil \\ E-mail: jfreitas.ap@gmail.com
}

\section{Erick Silva dos Santos}

Dept. of Botany, Institute of Scientific and Technological Research of the State of Amapá, Macapá, Brazil

E-mail: ericks_santos@hotmail.com

\section{Francisco de Oliveira Cruz Junior}

Dept. of Botany, Institute of Scientific and Technological Research of the State of Amapá, Macapá, Brazil

E-mail: francisco.florestal@bol.com.br

\section{César Henrique Alves Borges}

Dept. of Forest Science, Federal Rural University of Pernambuco (UFRPE), Recife, Pernambuco, Brazil

E-mail: cesarhenrique27@yahoo.com.br

Adriano Castelo dos Santos (Corresponding author)

Dept. of Botany, Institute of Scientific and Technological Research of the State of Amapá, Macapá, Brazil

E-mail: adrianocasteloeng@gmail.com

Received: Sep. 1, 2019

doi:10.5296/jas.v7i4.15366
Accepted: Sep. 28, 2019 Published: Oct. 7, 2019

URL: https://doi.org/10.5296/jas.v7i4.15366 


\section{Abstract}

Floristic surveys allow us to make a momentary assessment of the structure and degree of conservation of the vegetation, supporting future actions for the sustainable use of forest resources. The aim of this work was to study the floristic and structural composition of fragments of floodplain forest in the Cajari River Extractive Reserve, Amapá state, Brazil. Systematic sampling was applied with the allocation of 27 plots of dimensions $10 \mathrm{~m}$ x $100 \mathrm{~m}$ each, with inclusion level of individuals greater than or equal to $10 \mathrm{~cm}$ in diameter at chest height. The floristic diversity of species was determined by the Shannon Diversity Indexes and Pielou Equability. The characterization of the horizontal structure was determined by the parameters: density, frequency and relative and absolute dominance, values of ecological importance and the diametrical distribution. The families Fabaceae and Euphorbiaceae were the ones that obtained the highest richness of species and number of individuals. The species Virola surinamensis Warb., Hevea brasiliensis (HBK) Muell. Arg., Pentaclethra macroloba (Willd.) Kuntze and Mora paraensis (Ducke) Ducke, were the most abundant. The várzea forest fragments presented high diversity and high ecological dominance of species. The J-inverted diametric distribution, characteristic of natural forests, indicates that it is a mature forest component with an expressive group of dominating (hyperdominant) species, such as the species $V$. surinamensis and $M$. paraensis. Most species presented aggregate distribution. It is hoped that these results may serve the environmental control and control bodies as strategies for the use of forest resources and in the design of the management plan of Resex.

Keywords: forest ecology, flooded forest, Baixo Cajari

\section{Introduction}

Humid tropical forests are the major ecosystems in terms of the diversity of plant species in the world. The Amazon rainforest is rich in species, with a multitude of types of use for local populations. It is estimated that in this region there are around 16.000 plant species, with a very small group overlapping the others, dominating the area, 227 "hyperdominant" species (1.4\% of the total) are so common that together represent half of all the trees in the region, whereas the 11.000 most rare species account for only 0.12\% (Ter Steege et al., 2013).

Floodplain forests are the second most abundant type of vegetation in the Amazon, covering $75.880 .8 \mathrm{~km}^{2}$, representing $1.6 \%$ of the Amazon biome, constituting the second largest forest environment in the region in terms of structure, diversity and spatial representativeness (Queiroz \& Machado, 2008), as a result of the hydrogeomorphological dynamics of Amazonian river systems (Wittmann et al., 2010). However, in the last decades, large areas of these forests have been suppressed conventionally, without forest management (Miranda et al., 2018a).

In this sense, protecting and at the same time utilizing this range of forest resources requires knowledge about the ecology of these ecosystems and species (Wittmann et al., 2013, Costa et al., 2018). Strategies for the conservation of biological diversity require studies that quantify the species and their distribution in the environment. In addition, conservation initiatives, forest management, and forest fragments restoration require detailed studies on forest inventories and ecology of tree communities. 
Before any intervention in the forest, it is necessary to know about its various structural and functional parameters that regulate the forest dynamics (Montero et al., 2014; Santos et al., 2016). The estimation of parameters such as diversity, frequency, density, dominance and the diametric and spatial distributions of the species constitutes the study of the forest structure (Souza \& Soares, 2013). Phytosociology stands out as an effective instrument in the identification of plant richness, prior knowledge of the structural balance of the forest and main species destined to the use by local populations for income generation, assisting in the elaboration of forest management strategies.

With a view to the management of forest species and the conservation of forests, research that promotes knowledge about ecology, means of dispersion and distribution of species are fundamental for the elaboration of strategies of use and protection against the extinction of vulnerable and overexploited species, generating data scientists who prove the lethality of the conventional model of logging to biodiversity in the Amazon.

In this context, the Cajari River Extractive Reserve (Resex) is a federal conservation unit for the sustainable use of forest resources. It is located in the southern region of the state of Amapá (532.397.20 ha), which encompasses the municipalities of Mazagão, Laranjal do Jari and Vitória do Jari. The region is made up of 56 communities and 720 families, which survive from the Brazilian chestnut (Bertholletia excelsa Bonpl.) and native açaizal (Euterpe oleracea Mart.), Fishing, agricultural activities, and other non-timber forest resources (Freitas et al., 2018).

The objective of the study was to analyze the structure and floristic composition, diversity, spatial distribution and successional stage of the forest species in the section known as Baixo Cajari, in the Cajari River Extractive Reserve (Resex Cajari), Eastern Amazon, Brazil.

\section{Materials and Methods}

\subsection{Study Area}

The study was conducted on a stretch called Baixo Cajari within the limits of the Cajari River Extractive Reserve. Located in the southern region of the state of Amapá (00 $32^{\prime} 27 \mathrm{~S}$ and $051^{\circ} 51 \mathrm{\prime}$ ). Resex covers an area of 532.397.20 hectares, and access is by the Amazon River and by land, through BR 156 that integrates the municipalities of southern Amapá State (Figure 1). 


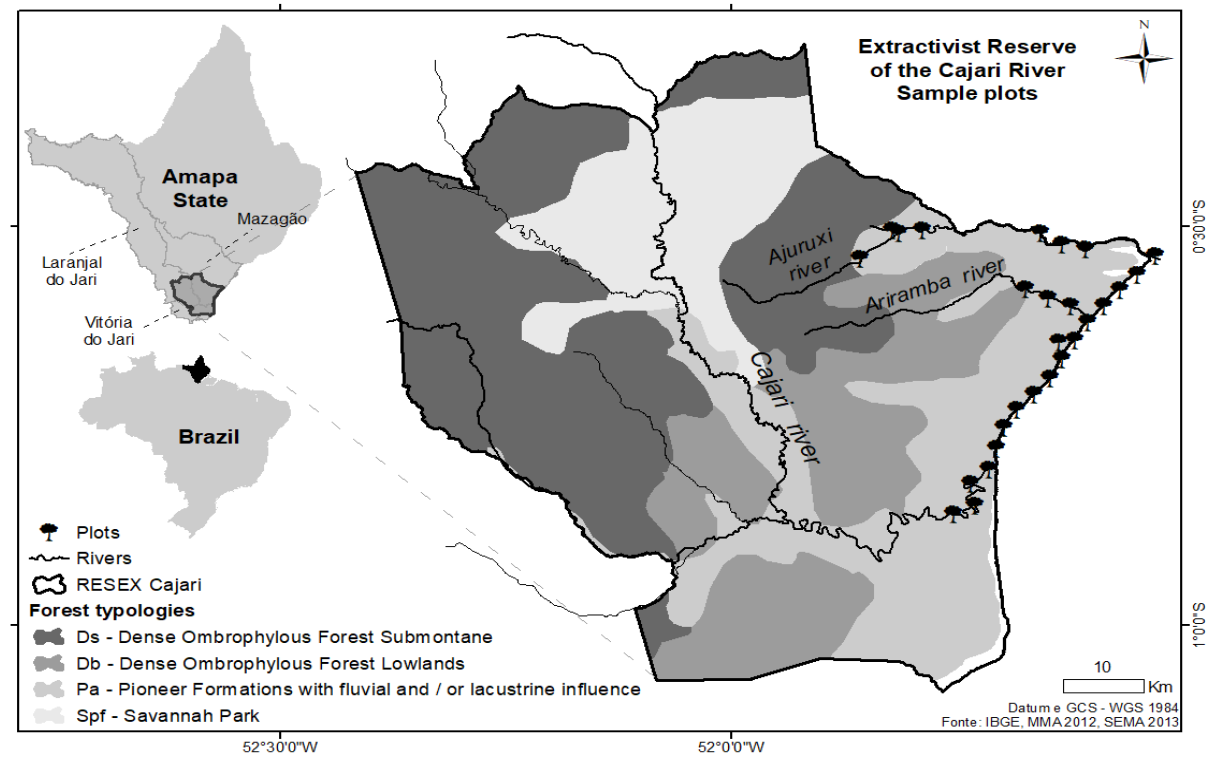

Figure 1. Location of the study area

The climate of the region is tropical Ami type, according to the classification of Koppen, with rainy season from January to July and annual average precipitation of $2.300 \mathrm{~mm}$ (Alvares et al., 2013). The predominant vegetation in the evaluated area is alluvial dense ombrophylous forest, that is, a high-level várzea forest with a large presence of palms, such as Euterpe oleracea Mart and Astrocaryum murumuru Mart.

\subsection{Data Collect}

The sampling of the forest inventory was systematic with allocation of 27 plots of $10 \times 100 \mathrm{~m}$ $\left(1000 \mathrm{~m}^{2}\right)$, equidistant $3 \mathrm{~km}$. All individuals of the arboreal component with diameter at breast height $(\mathrm{DBH})$ equal to or greater than $10 \mathrm{~cm}$ were identified and measured. The commercial height of the individuals was estimated with the aid of a $6 \mathrm{~m}$ graduated ruler positioned next to the stem of the tree measured. The botanical material of the species that could not be identified in the field was collected for analysis and taxonomic identification in the herbarium of the Institute of Scientific and Technological Research of Amapá (IEPA). To update and confirm the species nomenclature, the List of the Missouri Botanical Garden Tropicos (2018) and "the Plant List" database were used. The determination of families followed the classification system APG III (2009).

The floristic composition of the area was analyzed based on the number of families, genera and species of the tree component. The phytosociological parameters were calculated for each species. The vegetation horizontal structure was characterized by the following phytosociological parameters: density, frequency, dominance (relative and absolute) and value of ecological importance, as described in Souza \& Soares (2013).

The analysis of the diametrical distribution of individuals in diameter classes was performed by histogram, with the number and amplitude between the classes defined by the method of Sturges (1926). Diversity of species was evaluated by the Shannon Diversity Index (H ') and the Pielou Equability ( $\left.\mathrm{J}^{\prime}\right)$. 


\section{Macrothink

The classification in ecological groups and the analysis of the spatial distribution pattern were performed for the 10 highest density species in the area, based on field observations and literature review according to Gandolfi et al. (1995). Species were also categorized as pioneers, early secondary, late secondary or unclassified (NC). For the analysis of the spatial distribution pattern, the McGuinnes index (1934), which evaluates the degree of aggregation of the species, was obtained from the relation between observed density (Di) and the expected density (di), according to the following expressions:

$$
\mathrm{IGAi}=\frac{\mathrm{Di}}{\mathrm{di}} ; \mathrm{Di}=\frac{\mathrm{ni}}{\mathrm{UT}} ; \mathrm{di}=-\ln \left(1-\frac{\mathrm{Ui}}{\mathrm{UT}}\right)
$$

On what:

IGAi = McGuinnes index; $\mathrm{Di}=$ observed density of the ith species; di = expected density of the ith species; $\ln =$ logarithm neperian; $\mathrm{ni}=$ number of individuals sampled from the ith species; $\mathrm{Ui}=$ number of sample units that the ith species occurs; UT $=$ total number of sample units.

Sampling sufficiency was tested by the species accumulation curve. Processing, analysis of phytosociological data and sample sufficiency were performed in the Vegan software package R (R Core Team 2016).

\section{Results and Discussion}

\subsection{Sample Intensity}

The sampling intensity was tested by the cumulative curve of the species sampled in 2.7 hectares (Figure 2). From plot 20, the curve shows a tendency to stabilize, demonstrating that the number of parcels allocated was enough to characterize the area's richness.

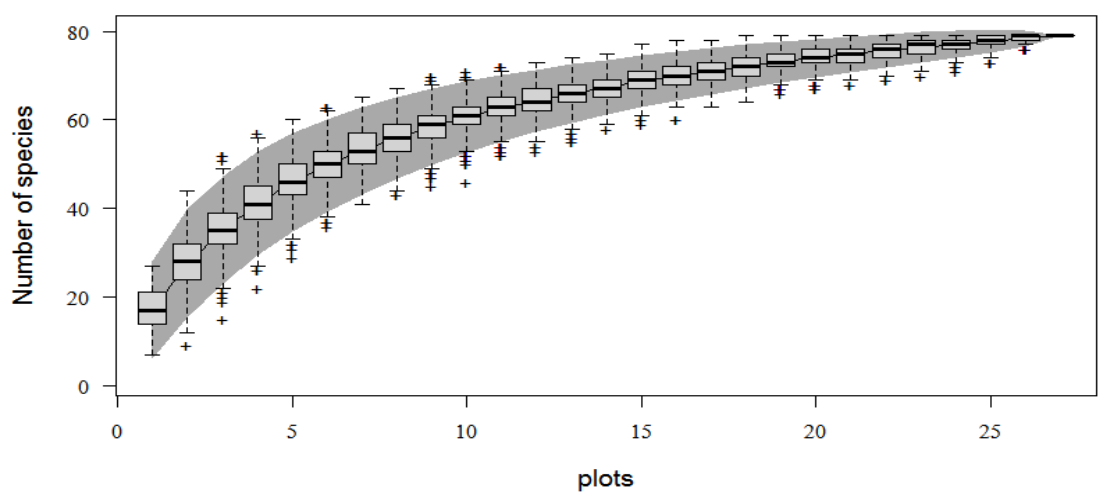

Figure 2. Estimate of sample adequacy by the cumulative curve of species in floodplain forest in the Cajari River Extractive Reserve, Eastern Amazon 


\section{Macrothink}

Our 27 allocated parcels were sufficient to the survey of tree vegetation. A significant sample intensity is important for a good sampling of the species richness in a given area, being a relation of the increment of the area sampled as a function of the number of species accumulated. The cumulative curve of species by area has often been used in phytosociological surveys to test sample adequacy (Hack et al., 2005). Considering a 10\% error for the floristic inventory, the plots were able to sample the richness of the tree component studied.

\subsection{Floristic Composition}

A total of 1.293 individuals were sampled in 27 botanical families, 64 genera and 78 species. The mean estimated height was $8.4 \mathrm{~m}$ and the maximum observed was $30 \mathrm{~m}$. The most representative family of individuals was Fabaceae (459). The families with the highest species richness were Fabaceae (18) and Chrysobalanaceae (five), concentrating 29\% of the total species raised. The 10 families with the highest abundance of individuals represent $83.8 \%$ of the total trees sampled in the area (Figure 3).

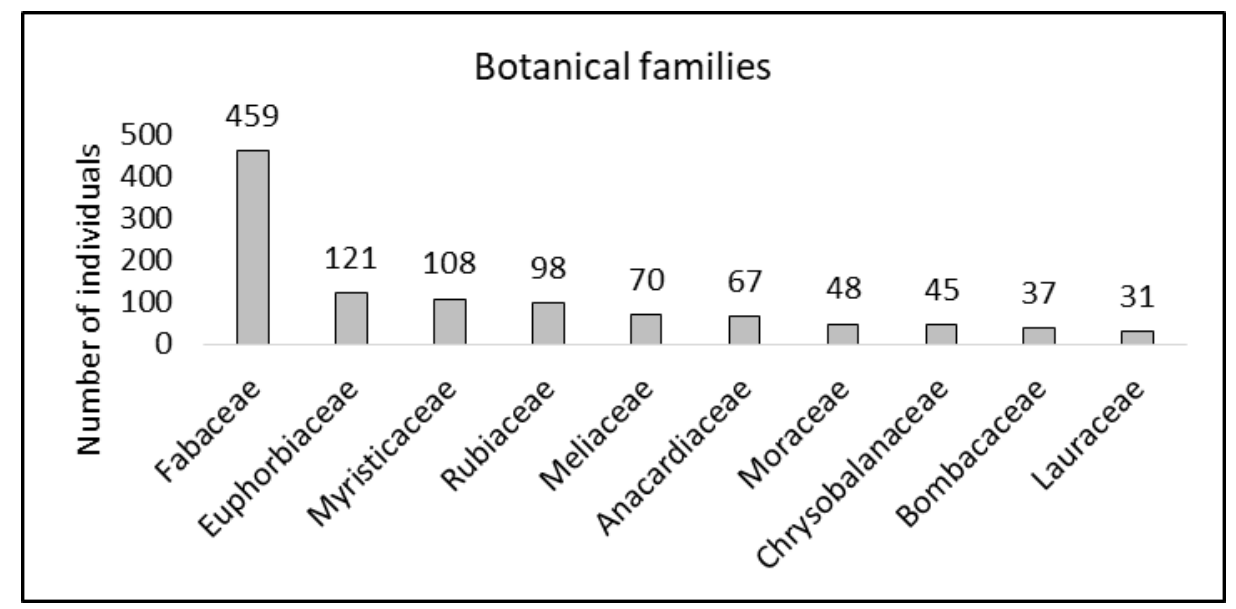

Figure 3. Botanical families with a decreasing distribution of the number of individuals in 2.4 ha of lowland forest in the Cajari River Extractivist Reserve

The Fabaceae family is one of the most abundant in lowland forests in the legal Amazon. Several studies have demonstrated its adaptability to the periodically flooded environment, especially in the states of Amapá (Santos et al., 2016; Sardinha et al., 2017), Pará (Maués et al., 2011; Lau \& Jardim, 2013) and Amazonas (Assis et al., 2017).

\subsection{Forest Structure}

The forest population had a density of $478.89 \pm 155.52$ ind. ha- ${ }^{1}$. The total basal area by area was $49.81 \pm 18.04 \mathrm{~m}^{2} \mathrm{ha}^{-1}$. The species richness was 78 (Table 1). 
Table 1. Phytosociological parameters for the species sampled in 2.7 ha of lowland forest in the Cajari River Extractivist Reserve, organized by decreasing order of absolute density (AD)

\begin{tabular}{|c|c|c|c|c|c|c|c|c|}
\hline Species & $\mathrm{Ni}$ & AD & DR & ADo & RDo & $\mathbf{A F}$ & RF & IV \\
\hline Virola surinamensis Warb. & 108 & 40.0 & 8.35 & 3.75 & 7.54 & 74.1 & 4.62 & 6.84 \\
\hline Hevea brasiliensis (HBK) Muell. Arg. & 106 & 39.3 & 8.2 & 5.29 & 10.6 & 74.1 & 4.62 & 7.81 \\
\hline Pentaclethra macroloba (Willd.) Kuntze & 102 & 37.8 & 7.89 & 1.96 & 3.94 & 74.1 & 4.62 & 5.48 \\
\hline Mora paraensis (Ducke) Ducke & 97 & 35.9 & 7.5 & 7.53 & 15.1 & 51.9 & 3.23 & 8.62 \\
\hline Calycophyllum spruceanum (Benth.) Hook. f. ex K. Schum. & 78 & 28.9 & 6.03 & 2 & 4.02 & 37 & 2.31 & 4.12 \\
\hline Spondias mombin L. & 64 & 23.7 & 4.95 & 4.21 & 8.45 & 70.4 & 4.39 & 5.93 \\
\hline Carapa guianensis Aubl. & 59 & 21.9 & 4.56 & 1.67 & 3.36 & 63 & 3.93 & 3.95 \\
\hline Swartzia polyphylla DC. & 44 & 16.3 & 3.4 & 2.93 & 5.88 & 29.6 & 1.85 & 3.71 \\
\hline Swartzia cardiosperma Spr. ex Benth. & 43 & 15.9 & 3.33 & 1.67 & 3.35 & 51.9 & 3.23 & 3.3 \\
\hline Platymiscium filipes Benth. & 36 & 13.3 & 2.78 & 0.87 & 1.74 & 40.7 & 2.54 & 2.36 \\
\hline Pachira aquatica Aubl. & 30 & 11.1 & 2.32 & 1.04 & 2.08 & 37 & 2.31 & 2.24 \\
\hline Inga $\mathrm{sp}$ & 25 & 9.26 & 1.93 & 0.43 & 0.86 & 40.7 & 2.54 & 1.78 \\
\hline Sarcaulus brasiliensis (A. DC.) Eyma & 24 & 8.89 & 1.86 & 0.28 & 0.56 & 40.7 & 2.54 & 1.65 \\
\hline Naucleopsis caloneura (Huber) Ducke & 23 & 8.52 & 1.78 & 1.62 & 3.26 & 44.4 & 2.77 & 2.6 \\
\hline Metrodorea flavida K. Krause & 23 & 8.52 & 1.78 & 0.28 & 0.55 & 33.3 & 2.08 & 1.47 \\
\hline Crudia pubescens Spruce ex Benth. & 22 & 8.15 & 1.7 & 0.92 & 1.86 & 29.6 & 1.85 & 1.8 \\
\hline Caryocar glabrum (Aubl.) Pers. & 19 & 7.04 & 1.47 & 1.07 & 2.14 & 22.2 & 1.39 & 1.67 \\
\hline Pterocarpus amazonicus Huber & 19 & 7.04 & 1.47 & 0.29 & 0.58 & 33.3 & 2.08 & 1.38 \\
\hline Chimarrhis barbata (Ducke) Bremek. & 18 & 6.67 & 1.39 & 0.21 & 0.42 & 29.6 & 1.85 & 1.22 \\
\hline Vatairea guianensis Aubl. & 17 & 6.3 & 1.31 & 0.48 & 0.96 & 25.9 & 1.62 & 1.3 \\
\hline Mouriri grandiflora DC. & 16 & 5.93 & 1.24 & 0.24 & 0.48 & 40.7 & 2.54 & 1.42 \\
\hline Licaria mahuba Kosterm & 16 & 5.93 & 1.24 & 0.36 & 0.72 & 33.3 & 2.08 & 1.34 \\
\hline Guazuma ulmifolia Lamarck & 16 & 5.93 & 1.24 & 0.4 & 0.8 & 22.2 & 1.39 & 1.14 \\
\hline Nectandra amazonum Ness & 15 & 5.56 & 1.16 & 0.35 & 0.7 & 33.3 & 2.08 & 1.31 \\
\hline Licania guianense Aubl. & 15 & 5.56 & 1.16 & 0.27 & 0.55 & 22.2 & 1.39 & 1.03 \\
\hline Cecropia leucoma Miquel & 14 & 5.19 & 1.08 & 0.18 & 0.37 & 29.6 & 1.85 & 1.1 \\
\hline Parinari campestris Aubl. & 13 & 4.81 & 1.01 & 0.79 & 1.58 & 18.5 & 1.15 & 1.25 \\
\hline Caraipa grandiflora Mart. & 13 & 4.81 & 1.01 & 0.79 & 1.58 & 14.8 & 0.92 & 1.17 \\
\hline Protium sp & 13 & 4.81 & 1.01 & 0.24 & 0.49 & 18.5 & 1.15 & 0.88 \\
\hline Licania heteromorpha Benth. & 11 & 4.07 & 0.85 & 0.73 & 1.46 & 25.9 & 1.62 & 1.31 \\
\hline Campsiandra laurifolia Benth. & 10 & 3.7 & 0.77 & 0.52 & 1.05 & 18.5 & 1.15 & 0.99 \\
\hline Sapium curupita Huber & 10 & 3.7 & 0.77 & 0.2 & 0.39 & 18.5 & 1.15 & 0.77 \\
\hline Xylopia sp & 10 & 3.7 & 0.77 & 0.1 & 0.2 & 14.8 & 0.92 & 0.63 \\
\hline Guatteria poeppigiana Mart. & 10 & 3.7 & 0.77 & 0.15 & 0.3 & 7.41 & 0.46 & 0.51 \\
\hline Macrolobium acaciaefolium Benth. & 9 & 3.33 & 0.7 & 0.7 & 1.4 & 14.8 & 0.92 & 1.01 \\
\hline Pithecellobium pedicellare (DC.) Benth. & 9 & 3.33 & 0.7 & 0.31 & 0.62 & 18.5 & 1.15 & 0.82 \\
\hline Gustavia augusta $\mathrm{L}$. & 9 & 3.33 & 0.7 & 0.11 & 0.22 & 3.7 & 0.23 & 0.38 \\
\hline Ficus anthelminthica Mart. & 8 & 2.96 & 0.62 & 0.58 & 1.16 & 18.5 & 1.15 & 0.98 \\
\hline Cedrela odorata $\mathrm{L}$. & 7 & 2.59 & 0.54 & 0.19 & 0.38 & 14.8 & 0.92 & 0.61 \\
\hline Tachigalia paniculata Aubl. & 7 & 2.59 & 0.54 & 0.12 & 0.24 & 7.41 & 0.46 & 0.42 \\
\hline Hernandia guianensis Aubl. & 6 & 2.22 & 0.46 & 0.27 & 0.55 & 18.5 & 1.15 & 0.72 \\
\hline Macrolobium augustifolium R.S.Cowan & 6 & 2.22 & 0.46 & 0.31 & 0.63 & 14.8 & 0.92 & 0.67 \\
\hline Pterocarpus officinalis Jacq. & 6 & 2.22 & 0.46 & 0.4 & 0.79 & 11.1 & 0.69 & 0.65 \\
\hline Calophyllum brasiliensis Cambess. & 6 & 2.22 & 0.46 & 0.12 & 0.24 & 18.5 & 1.15 & 0.62 \\
\hline Casearia arborea (Rich.) Urb. & 6 & 2.22 & 0.46 & 0.15 & 0.31 & 14.8 & 0.92 & 0.57 \\
\hline Licania macrophylla Benth. & 5 & 1.85 & 0.39 & 0.06 & 0.12 & 18.5 & 1.15 & 0.55 \\
\hline Hura crepitans Muell. Arg. & 5 & 1.85 & 0.39 & 0.13 & 0.26 & 14.8 & 0.92 & 0.52 \\
\hline Protium pubescens (Benth.) Engl. & 5 & 1.85 & 0.39 & 0.09 & 0.17 & 11.1 & 0.69 & 0.42 \\
\hline Didymopanax morototoni (Aubl.) Decne. \& Planch. & 4 & 1.48 & 0.31 & 0.14 & 0.28 & 7.41 & 0.46 & 0.35 \\
\hline Terminalia guianensis Aubl. & 3 & 1.11 & 0.23 & 0.69 & 1.38 & 11.1 & 0.69 & 0.77 \\
\hline Tapirira guianensis Aubl. & 3 & 1.11 & 0.23 & 0.13 & 0.26 & 11.1 & 0.69 & 0.4 \\
\hline Sterculia speciosa K. Schum & 3 & 1.11 & 0.23 & 0.07 & 0.15 & 11.1 & 0.69 & 0.36 \\
\hline Trichilia surinamensis (Miq.) C. DC. & 3 & 1.11 & 0.23 & 0.06 & 0.13 & 11.1 & 0.69 & 0.35 \\
\hline Inga edulis Mart. & 3 & 1.11 & 0.23 & 0.12 & 0.24 & 7.41 & 0.46 & 0.31 \\
\hline Artocarpus incisa L. & 3 & 1.11 & 0.23 & 0.11 & 0.22 & 7.41 & 0.46 & 0.3 \\
\hline Symphonia globulifera L. & 3 & 1.11 & 0.23 & 0.06 & 0.12 & 7.41 & 0.46 & 0.27 \\
\hline Peltogyne catingae Ducke & 3 & 1.11 & 0.23 & 0.06 & 0.12 & 7.41 & 0.46 & 0.27 \\
\hline
\end{tabular}




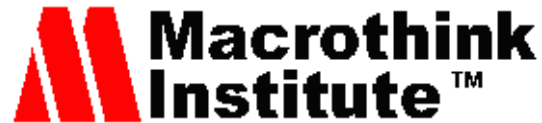

\begin{tabular}{lrrrrrrrr}
\hline \multicolumn{1}{c}{ Species } & Ni & AD & DR & ADo & RDo & AF & RF & IV \\
\hline Matisia paraensis Huber & 3 & 1.11 & 0.23 & 0.06 & 0.12 & 3.7 & 0.23 & 0.19 \\
Caryocar villosum (Aubl.) Pers. & 2 & 0.74 & 0.15 & 0.26 & 0.53 & 7.41 & 0.46 & 0.38 \\
Apeiba burchelli Sprague & 2 & 0.74 & 0.15 & 0.07 & 0.14 & 7.41 & 0.46 & 0.25 \\
Genipa americana L. & 2 & 0.74 & 0.15 & 0.05 & 0.1 & 7.41 & 0.46 & 0.24 \\
Lecythis lurida (Miers) Mori & 2 & 0.74 & 0.15 & 0.02 & 0.05 & 7.41 & 0.46 & 0.22 \\
Mouriri princeps Naudin & 2 & 0.74 & 0.15 & 0.02 & 0.04 & 7.41 & 0.46 & 0.22 \\
Maytenus sp & 2 & 0.74 & 0.15 & 0.02 & 0.04 & 7.41 & 0.46 & 0.22 \\
Ceiba pentandra (L.) Gaertn. & 2 & 0.74 & 0.15 & 0.13 & 0.25 & 3.7 & 0.23 & 0.21 \\
Quararibea guianensis Aubl. & 2 & 0.74 & 0.15 & 0.05 & 0.11 & 3.7 & 0.23 & 0.16 \\
Minquartia guianensis Aubl. & 2 & 0.74 & 0.15 & 0.01 & 0.03 & 3.7 & 0.23 & 0.14 \\
Pouteria sagotiana (Baill.) Eyma & 1 & 0.37 & 0.08 & 0.13 & 0.26 & 3.7 & 0.23 & 0.19 \\
Xylopia amazonica R.E.FR. & 1 & 0.37 & 0.08 & 0.05 & 0.1 & 3.7 & 0.23 & 0.14 \\
Allantoma lineata (Mart. \& O.Berg) Miers & 1 & 0.37 & 0.08 & 0.03 & 0.07 & 3.7 & 0.23 & 0.12 \\
Trichilia paraensis C. DC. Da & 1 & 0.37 & 0.08 & 0.03 & 0.06 & 3.7 & 0.23 & 0.12 \\
Pouteria biloculares Baehni & 1 & 0.37 & 0.08 & 0.03 & 0.05 & 3.7 & 0.23 & 0.12 \\
Ormosia coutinhoi Ducke & 1 & 0.37 & 0.08 & 0.02 & 0.05 & 3.7 & 0.23 & 0.12 \\
Vismia guianensis (Aubl.) Choisy & 1 & 0.37 & 0.08 & 0.01 & 0.02 & 3.7 & 0.23 & 0.11 \\
Pouteria macrophylla (Lam.) Eyma & 1 & 0.37 & 0.08 & 0.01 & 0.02 & 3.7 & 0.23 & 0.11 \\
Licania kunthiana H.F. & 1 & 0.37 & 0.08 & 0 & 0.01 & 3.7 & 0.23 & 0.11 \\
Malouetia tamaraquina (Aublet) A.D.C. & 1 & 0.37 & 0.08 & 0 & 0.01 & 3.7 & 0.23 & 0.11 \\
Theobroma speciosum Willd. Ex Spreng. & 1 & 0.37 & 0.08 & 0 & 0.01 & 3.7 & 0.23 & 0.11 \\
\hline Total & $\mathbf{1 2 9 3}$ & $\mathbf{4 7 8 . 8}$ & $\mathbf{1 0 0}$ & $\mathbf{4 9 . 8}$ & $\mathbf{1 0 0 . 0}$ & - & $\mathbf{1 0 0}$ & $\mathbf{1 0 0 . 0}$ \\
\hline & & & & & & & &
\end{tabular}

* Number of individuals (Ni), Absolute density (AD), relative density (DR), absolute dominance (ADo), relative dominance (RDo), absolute frequency (AF), relative frequency (RF) and importance value (IV).

The study corroborated with other researches in the Amazon, presenting relevant richness of vegetal species. Sardinha et al. (2017), in 3 ha of lowland rainforest area in the Amazon River estuary, identified 65 species. Santos et al. (2016), in 2 ha of area in the Eastern Amazon, 26 species. Ferreira et al. (2013), in 2 ha of lowland forest in the Eastern Amazon, 48 species. Lau \& Jardim (2013), in 2.7 hectares of lowland forest in the Amazon estuary, 61 species.

Regarding the number of individuals (Ni) and Value of Importance (IV) we highlight the species Virola surinamensis, Mora paraensis, Calycophyllum spruceanum, with great potential for timber production in the studied area and for non-wood production we highlight Hevea brasiliensis (Latex), Pentaclethra macroloba (oil), Spondias mombin (fruits) and Carapa guianensis (seed oil).

\subsection{Absolute Density}

Among the 10 species of highest value for the parameter absolute density (AD), we highlight Virola surinamensis, Pentaclethra macroloba, Hevea brasiliensis and Mora paraensis (Figure 4). 


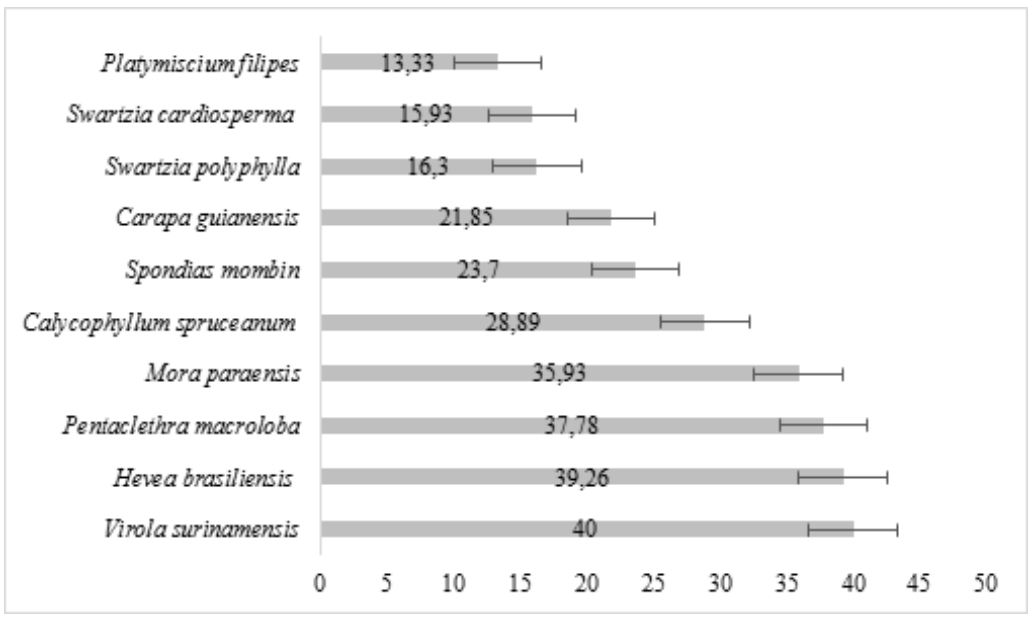

Figure 4. Absolute density (ind. ha- ${ }^{1}$ ) by species in 2.7 ha of lowland forest

The species $V$. surinamensis (Ucuúba-da-várzea) is a large tree and abundant in lowland forests of the Amazon River estuary (Batista et al., 2011). The species is considered of multiple use, with good wood and of great employability in the civil construction, has a history of great superexploration in the Amazon region, mainly in the decade of 1980, and for that reason it was included in the list of endangered species) according to ordinance of the Ministry of the Environment No 443/2014 (Brazil, 2014).

The predominance in density of few species in lowland forests in the Amazon is often evidenced in research (Queiroz \& Machado, 2008; Santos et al., 2013; Sardinha et al., 2017). Ter Steege et al. (2013) concluded in their study on the Amazon region that most of the dominant species in one environment are habitat specialists who have large geographic areas but are dominant only in one or two regions of the basin and an average of $41 \%$ of trees in sample plots belong to hyperdominant species. The authors also report that a disproportionate number of hyperdominants are from the families Arecaceae, Myristicaceae and Lecythidaceae.

\subsection{Diameter Distribution}

The arithmetic mean of the diameters was $31.57 \mathrm{~cm}$ and the maximum value was $145.10 \mathrm{~cm}$. Naucleopsis caloneura was the species with the highest DBH $(145.10 \mathrm{~cm})$, followed by Swartzia polyphylla $(143.2 \mathrm{~cm})$, Swartzia cardiosperma $(105 \mathrm{~cm})$ and Mora paraensis (105 $\mathrm{cm})$. The pattern of diametric distribution of the individuals was J-inverted, following the trend for native forests with a low degree of anthropization, with a larger number of individuals in the smaller diameter classes and a progressive decrease with increasing diameter class (Figure 5). 


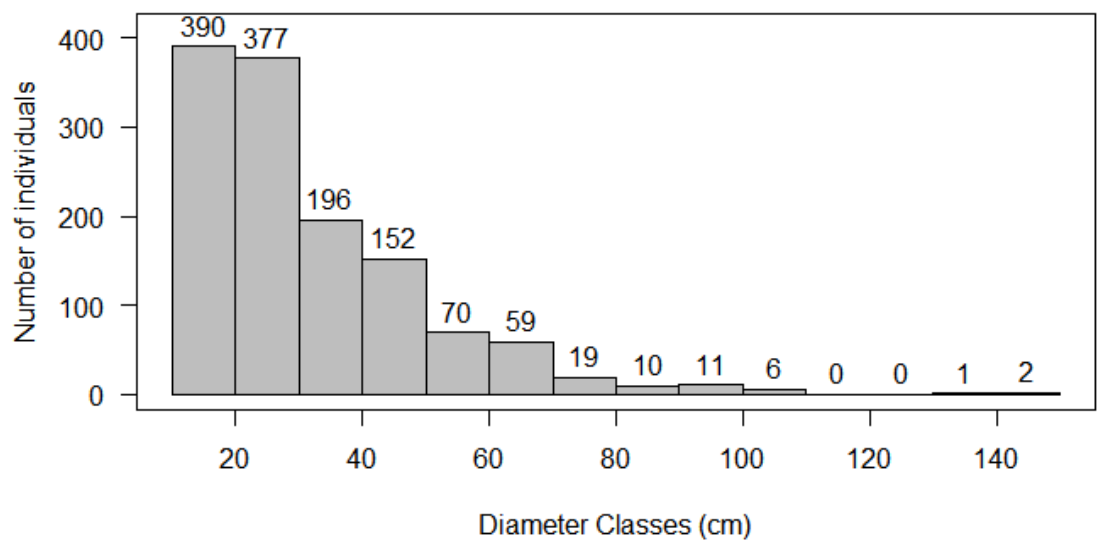

Figure 5. Distribution in diameter classes of individuals sampled with $\mathrm{DBH} \geq 10 \mathrm{~cm}$ in 2.4 ha of lowland forest

The diametric distribution is characteristic of natural forests, this research corroborates with other works in the Amazonian floodplain (Santos et al., 2013; Sardinha et al., 2017), which number of individuals in smaller diameter classes, indicating that it is a factor associated to the natural dynamics typical of natural tropical forests, whose high number of regenerating individuals compensates the mortality over time, thus ensuring the species' perpetuation over time and the equilibrium of the plant community. Knowledge about the diametric structure of a forest is an important tool for low impact forest management and forest planning.

\subsection{Floristic Diversity}

The diversity index of Shannon was 3.60 nats. ind. ${ }^{-1}$ and the Pielou Equability index (J') 0.83 . The results are close to those found by Maués et al. (2011) in várzea in Pará: 3.72 nats. ind. ${ }^{-1}$ and $J^{\prime}=0.69$. Other studies found lower results in Amazonian floodplains: 2.96 nats. ind $^{-1}$ (Sardinha et al., 2017) and 2.84 nats. ind. ${ }^{-1}$ (Santos et al., 2016) in Amapá; and 2.32 nats. ind. $^{-1}$ in the states of Amapá and Pará (Queiroz \& Machado, 2008). A possible cause for these low values of floristic diversity may be related to the intense logging of the floodplains of the Amazonian estuary in the 1980s and 1990s to supply the region's rolling mills (Barros \& Uhl, 1997).

\subsection{Commercial Volume and Basal Area}

The total commercial volume was $1477.79 \mathrm{~m}^{3}$, with a mean of $547.32 \mathrm{~m}^{3} \mathrm{ha}^{-1}$. The 10 species with the highest commercial volume represented $66.7 \%$ of the total (Figure 6). 


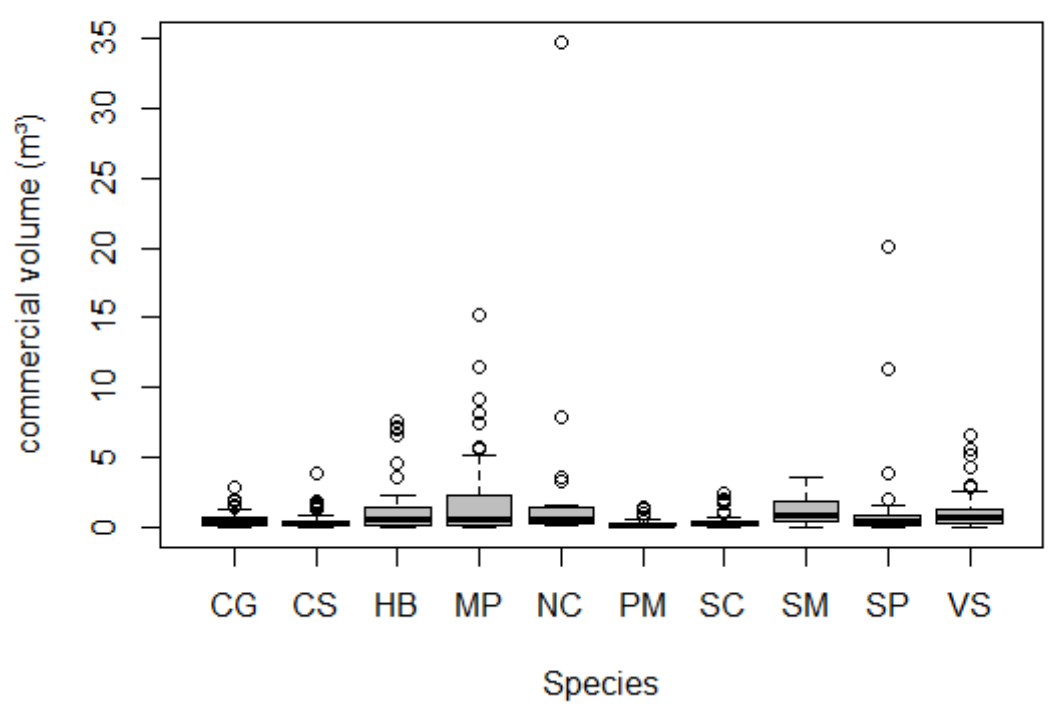

Figure 6. Commercial volume $\left(\mathrm{m}^{3} \mathrm{ha}^{-1}\right)$ by species and their Confidence Intervals in 2.7 ha of lowland forest. The boxes represent 25 and 75 quartiles and the line represents the median. $C$. guianensis (CG), C. spruceanum (CS), H. brasiliensis (HB), M. paraensis (MP), $N$. caloneura (NC), P. macroloba (PM), S. mombin (SM) S. cardiosperm (SC), S. polyphylla (SP) and V. surinamensis (VS)

The species $M$. paraensis (Pracuubeira) was distinguished by the greater volume in the area sampled, reaching more than $50 \%$ of the average volume per hectare. Miranda et al. (2018b) highlight $M$. paraensis because it presents high abundance of regenerating individuals in lowland forests of the Amazonian estuary, which guarantees the supply of juvenile plants necessary for the replacement of adults who die naturally or are extracted for wood. This ecological strategy of the species certainly ensures that the timber stock is constantly renewed.

The absolute dominance was $49.81 \mathrm{~m}^{2} \mathrm{ha}^{-1}$. The 9 species with the highest commercial volume $\left(\mathrm{m}^{3} \mathrm{ha}^{-1}\right)$ represent $62.3 \%$ of the total area dominance. In a similar study in two floodplains in Mato Grosso, Batista et al. (2011) found values smaller than 26.6 and $35-3 \mathrm{~m}^{2}$ $\mathrm{ha}^{-1}$. In várzea forest, the result was higher than that found by Sardinha et al. (2017), of 26.6 $\mathrm{m}^{2} \mathrm{ha}^{-1}$, but smaller than Santos et al. (2016), of $77.2 \mathrm{~m}^{2} \mathrm{ha}^{-1}$.

According to Martins (2012), dominance is an attribute used to represent vegetation biomass. Analyzing the dominance at the species level, M. paraensis, H. brasiliensis, S. mombin and $V$. surinamensis are the most prominent. The last species is one of the most frequent in Amazonian floodplains, either in Pará (Lau \& Jardim, 2013) or in Amazonas (Assis et al., 2017). 


\section{Ml Macrothink}

Journal of Agricultural Studies

ISSN 2166-0379

2019, Vol. 7, No. 4

\subsection{Spatial Distribution}

The majority of the species showed an aggregate distribution pattern, especially Spondias mombin and Naucleopsis caloneura, which tended to cluster (Table 2).

Table 2. Spatial distribution of species in várzea forest in the Cajari River Extractivist Reserve

\begin{tabular}{lccl}
\hline \multicolumn{1}{c}{ Species } & Ni & IGA & Distribution \\
\hline Mora paraensis & 97 & 4.92 & Aggregate \\
Hevea brasiliensis & 106 & 2.91 & Aggregate \\
Virola surinamensis & 108 & 2.96 & Aggregate \\
Spondias mombin & 64 & 1.95 & Grouping trend \\
Pentaclethra macroloba & 102 & 2.80 & Aggregate \\
Calycophyllum spruceanum & 78 & 6.24 & Aggregate \\
Carapa guianensis & 59 & 2.20 & Aggregate \\
Swartzia polyphylla & 44 & 4.64 & Aggregate \\
Swartzia cardiosperma & 43 & 2.18 & Aggregate \\
Naucleopsis caloneura & 23 & 1.45 & Grouping trend \\
\hline
\end{tabular}

* Ni: number of individuals; IGA: McGuinnes Index.

Tropical forests have high spatial and temporal heterogeneity, which strongly influences species distribution patterns (Gris et al., 2014). In flooded tropical forests, the dispersion of seeds promoted by the daily entrance of the tides acts as a relevant factor in determining the spatial pattern of numerous species. Another factor that may influence the spatial distribution is the dispersion syndrome characteristic of each species.

\subsection{Ecological Groups}

The species Calycophyllum spruceanum and Virola surinamensis were the ones that stood out for being classified in the successional group of the pioneers, requiring greater luminosity in the environment for its development (Table 3). 
Table 3. Ecological groups and dispersion syndrome of the 10 higher density species in lowland forest in the Cajari River Extractivist Reserve

\begin{tabular}{|c|c|c|c|}
\hline Species & DS & EG & Use \\
\hline Mora paraensis & $\begin{array}{l}\text { Barochory, } \\
\text { hidrochory }\end{array}$ & $\begin{array}{c}\text { Late secondary (slow growth, } \\
\text { upper canopy) }\end{array}$ & $\begin{array}{c}\text { White wood, Carpentry, } \\
\text { Wood beams, Construction, } \\
\text { Shipbuilding }\end{array}$ \\
\hline Hevea brasiliensis & Zoochoric & $\begin{array}{l}\text { Initial secondary (medium } \\
\text { canopy, moderate growth) }\end{array}$ & Natural rubber, latex, Oil. \\
\hline Virola surinamensis & $\begin{array}{l}\text { Zoochoric, } \\
\text { hidrochory }\end{array}$ & Pioneer (slow growth) & $\begin{array}{l}\text { White wood, compensated, } \\
\text { energy production, Piles, } \\
\text { crafts, toothpicks. }\end{array}$ \\
\hline Spondias mombin & Barochory & Late secondary (upper canopy) & $\begin{array}{l}\text { Human and animal feeding, } \\
\text { folk medicine, White wood. }\end{array}$ \\
\hline Pentaclethra macroloba & Hidrochory & $\begin{array}{l}\text { Late secondary, (medium } \\
\text { canopy, slow growth) }\end{array}$ & $\begin{array}{l}\text { Folk medicine, Oil, Wood, } \\
\text { furniture, firewood. }\end{array}$ \\
\hline Calycophyllum spruceanum & Anemochoric & $\begin{array}{l}\text { Pioneer (fast growth, } \\
\text { intermediate canopy) }\end{array}$ & $\begin{array}{l}\text { Mixed wood, Construction, } \\
\text { carpentry, energy production. }\end{array}$ \\
\hline Carapa guianensis & $\begin{array}{l}\text { Autochoric, } \\
\text { hidrochory, } \\
\text { Zoochoric }\end{array}$ & $\begin{array}{c}\text { Late secondary } \\
\text { (slow growth, medium canopy) }\end{array}$ & $\begin{array}{l}\text { Red wood, Construction and } \\
\text { Shipbuilding, compensated, } \\
\text { folk medicine. }\end{array}$ \\
\hline Swartzia polyphylla & Hidrochory & $\begin{array}{l}\text { Initial secondary (moderate } \\
\text { growth, medium canopy) }\end{array}$ & Mixed wood, animal feed. \\
\hline Swartzia cardiosperma & $\begin{array}{l}\text { Zoochoric, } \\
\text { hidrochory }\end{array}$ & Initial secondary (slow growth) & Mixed wood, animal feed, \\
\hline Naucleopsis caloneura & Zoochoric & $\begin{array}{r}\text { Late secondary } \\
\text { (slow growth) }\end{array}$ & White wood, crafts. \\
\hline
\end{tabular}

* DS: dispersion syndrome; EG: ecological group.

Another factor that may influence the spatial distribution is the dispersion syndrome characteristic of each species. In general, the species presented a syndrome of dispersion by hydrochory, influenced by the conditions of the habitat in which they are inserted and by the water regime of the tides in the region of the Amazonian estuary. In lowland forests some floating seeds can provide large seedling banks around the maternal plant, as observed in the study for M. paraensis, P. macroloba and C. guianensis. V. surinamensis stands out due to its fruiting throughout the year and its high germination capacity because they are tolerant to shade (Maués et al. 2011). The species presents a deep and dense root system, relatively rapid growth and high biomass production (Andrade Junior et al., 2019), a decisive factor for its germination and establishment of seedlings.

\section{Conclusion}

The J-inverted diametric distribution, characteristic of unequal natural forests, indicates that the studied forest component is in mature forest stage, with an expressive group of dominating (hyperdominant) species such as $V$. surinamensis and M. paraensis. Most of the evaluated species had an aggregate distribution pattern, with only the $S$. mombin and $N$. caloneura species with a tendency to group the individuals. In general, the species belong to the successional group of late and/or initial secondary.

Studies on forest structure and dynamics and species distribution are essential for the elaboration of forest management plans, the timber market, creation of strategies for multiple uses of forest products, mainly by local populations, rationalization of operational costs, 
conservation minimization of impacts.

The results contribute essential data to the recommendations for classification and management of areas for exploitation of non-timber forest products such as andiroba oil $(C$. guianenis), pracaxi oil (P. macroloba) and timber species such as $V$. surinamensis and $M$. paraensis in the Cajari River Extractive Reserve. The species distribution in the area and the dispersal mode are also strategic information for the elaboration of resource exploitation plans directed to each species.

\section{References}

Alvares, C. A. et al. (2013). Köpen's climate classification map for Brazil. Meteorologische Zeitschrift, 22, 711-728. https://doi.org/10.1127/0941-2948/2013/0507

Andrade Junior, W. V. et al. (2019). Effect of cadmium on young plants of Virola surinamensis. AoB Plants, 11, 1-11. https://doi.org/10.1093/aobpla/plz022

APG III. (2009). Angiosperm Phylogeny Group classification for the orders and families of flowering plants: APG III. Botanical Journal of the Linnean Society 161, 105-121. https://doi.org/10.1111/j.1095-8339.2009.00996.x

Assis, R. L., Wittmann, F., Luize, B. G., \& Haugaasen, T. (2017). Patterns of floristic diversity and composition in floodplain forests across four Southern Amazon river tributaries, Brazil. Flora, 229, 124-140. https://doi.org/10.1016/j.flora.2017.02.019

Barros, A. C., \& Uhl, C. (1997). Logging along the Amazon River and estuary: Patterns, problems and potential. Belém, Brasil: IMAZOM. Série Amazônia 4, 42 pp.

Batista, F. J. et al. (2011). Comparação florística e estrutural de duas florestas de várzea no estuário amazônico, Pará, Brasil. Revista Árvore 35, 289-298.

https://doi.org/10.1590/S0100-67622011000200013

Brasil (2014). Ministério do Meio Ambiente. Portaria MMA No 443 (Ministry of the Environment, MMA Ordinance No. 443), de 17 de Dezembro de 2014.

http://cncflora.jbrj.gov.br/portal/static/pdf/portaria_mma_443_2014.pdf

Costa, D. L. et al. (2018). Estrutura e distribuição espacial de Symphonia globulifera L. f. em floresta de várzea baixa, Afuá-PA. Advances in Forestry Science, 5(1), 275-281. file:///D:/Artigo_JAStudies/Costa.etal2018.carzea.floristic.pdf

Ferreira, L. V. et al. (2013). Variação da riqueza e composição de espécies da comunidade de plantas entre as florestas de igapós e várzeas na estação científica Ferreira Penna-Caxiuanã na Amazônia oriental. Pesquisa Botânica, 64, 175-195.

Freitas, J. L. et al. (2018). Composição florística arbórea em reserva extrativista no Amapá. Revista em Agronegócio e Meio Ambiente, 11, 277-300.

https://doi.org/10.17765/2176-9168.2018v11n1p277-300

Gandolfi, S., Leitão Filho, H. F., \& Bezerra, C. L. F. (1995). Levantamento florístico e caráter sucessional das espécies arbustivo-arbóreas de uma floresta semidecídua no município de 
Guarulhos, SP. Revista Brasileira de Biologia, 55, 753-767.

Gris, D., Temponi, L. G., \& Damasceno Junior, G. A. (2014). Structure and floristic diversity of remnant semideciduous forest under varying levels of disturbance. Acta Botanica Brasilica, 28, 569-576. https://doi.org/10.1590/0102-33062014abb3432

Hack, C. et al. (2005). Análise fitossociológica de um fragmento de Floresta estacional decidual no município de Jaguari, Rs. Ciência Rural, 35, 1083-1091.

https://doi.org/10.1590/S0103-84782005000500015

Lau, A. V., \& Jardim, M. A. G. (2013). Florística e estrutura da comunidade arbórea em uma floresta de várzea na Área de Proteção Ambiental, Ilha do Combu, Belém, Pará. Biota Amazônia, 3, 88-93. https://doi.org/10.18561/2179-5746/biotaamazonia.v3n2p88-93

Martins, S. V. (2012). Restauração ecológica de ecossistemas degradados (Ecological restoration of degraded ecosystems). Viçosa: Editora UFV, 293 p.

Maués, B. A. R. (2011). Composição florística e estrutura do estrato inferior da floresta de várzea na área de proteção ambiental ilha do Combu, município de Belém, estado do Pará. Revista Árvore, 35, 669-677. https://doi.org/10.1590/S0100-67622011000400011

Mcguinnes, W. G. (1934). The relationship between frequency index and abundance as applied to plant populations in a semi-arid region. Ecology, Durham, 16, 263-282. https://doi.org/10.2307/1932468

Miranda, Z. P. et al. (2018a). Volume increment modeling and subsidies for the management of the tree Mora paraensis (Ducke) Ducke based on the study of growth rings. Trees, 32, 277-286. https://doi.org/10.1007/s00468-017-1630-7

Miranda, Z. P. et al. (2018b). Natural Regeneration Dynamics of Mora paraensis (Ducke) Ducke in Estuarine Floodplain Forests of the Amazon River. Forests, 9(54). https://doi.org/10.3390/f9020054

Missouri Botanical Garden. (2018). TROPICOS. http://www.tropicos.org

Montero, J. C., Piedade, M. T. F., \& Wittmann, F. (2014). Floristic variation across $600 \mathrm{~km}$ of inundation forests (Igapó) along the Negro River, Central Amazonia. Hydrobiologia, 729,229-246. https://doi.org/10.1007/s10750-012-1381-9

Queiroz, J. A. L., \& Machado, S. A. (2008). Fitossociologia em floresta de várzea do estuário amazônico no Estado do Amapá. Pesquisa Florestal Brasileira 57, 05-20. https://doi.org/10.5380/rf.v37i3.9930

R Core Team. (2016). R: A language and environment for statistical computing. R Foundation for Statistical Computing, Vienna, Austria. https://www.R-project.org/.

Santos, E. S. et al. (2013). Estrutura da espécie Virola surinamensis (Rol.) Ward na floresta estadual do Amapá- FLOTA/AP. Revista de Biologia e Ciências da Terra, 13, 48-61.

Santos, R. O. et al. (2016). Processos amostrais para estimativa de parâmetros estruturais de 
uma floresta estuarina no estado do Amapá. Nativa, 4, 308-316. https://doi.org/10.14583/2318-7670.v04n05a07

Sardinha, M. A. et al. (2017). Florística e utilização de espécies florestais em assentamento agroextrativista, Amapá, Amazônia Oriental. Enciclopédia Biosfera, 14(26), 595-610. https://doi.org/10.18677/EnciBio_2017B33

Souza, A. L., \& Soares, C. P. B. (2013). Florestas Nativas: estrutura, dinâmica e manejo (Native Forests: structure, dynamics and management). Editora UFV, 322 p.

Sturges, H. A. (1926). The choice of a class interval. Journal of the American Statistical Association, 21(153), 65-66. https://doi.org/10.1080/01621459.1926.10502161

Ter Steege, H. et al. Hyperdominance in the Amazonian Tree Flora. Science 342, 1243092. https://doi.org/10.1126/science.1243092

Wittmann, F. et al. (2010). Manual de árvores de várzea da Amazônia Central. Editora INPA, 2010, 286p.

Wittmann, F. et al. (2013). Habitat specifity, endemism and the neotropical distribution of Amazonian white-water floodplain trees. Ecography 36, 690-707.

https://doi.org/10.1111/j.1600-0587.2012.07723.x

\section{Copyright Disclaimer}

Copyright for this article is retained by the author(s), with first publication rights granted to the journal.

This is an open-access article distributed under the terms and conditions of the Creative Commons Attribution license (http://creativecommons.org/licenses/by/4.0/). 